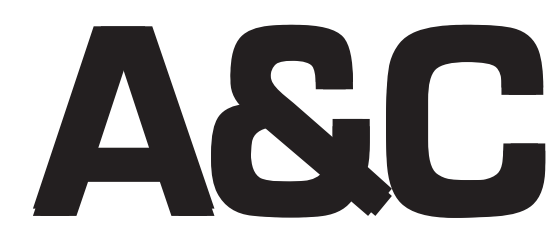

Revista de Direito Administrativo \& Constitucional

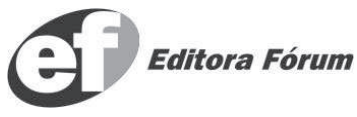

ISSN 1516-3210 


\section{A\&C REVISTA DE DIREITO ADMINISTRATIVO \& CONSTITUCIONAL}

\section{IPDA}

Instituto Paranaense

de Direito Administrativo

Direção Geral

Romeu Felipe Bacellar Filho

Direção Editorial

Paulo Roberto Ferreira Motta

Direção Executiva

Emerson Gabardo

Conselho de Redação

Edgar Chiuratto Guimarães

Adriana da Costa Ricardo Schier

Célio Heitor Guimarães

\section{Conselho Editorial}

Adilson Abreu Dallari (Brasil) Alice Gonzales Borges (Brasil) Antonello Tarzia (Itália)

Carlos Ari Sundfeld (Brasil)

Carlos Ayres Britto (Brasil)

Carlos Delpiazzo (Uruguai)

Cármen Lúcia Antunes Rocha (Brasil)

Celso Antônio Bandeira de Mello

(Brasil)

Clèmerson Merlin Clève (Brasil)

Clovis Beznos (Brasil)

Enrique Silva Cimma (Chile)

Eros Roberto Grau (Brasil)

Fabrício Motta (Brasil)

Guilhermo Andrés Muñoz - in memoriam

(Argentina)

Jaime Rodríguez-Arana Muñoz (Espanha)

Jorge Luís Salomoni - in memoriam
(Argentina)
José Carlos Abraão (Brasil)
José Eduardo Martins Cardoso (Brasil)
José Luís Said (Argentina)
José Mario Serrate Paz (Uruguai)
Juan Pablo Cajarville Peruffo (Uruguai)
Juarez Freitas (Brasil)
Julio Rodolfo Comadira - in memoriam
(Argentina)
Luís Enrique Chase Plate (Paraguai)
Lúcia Valle Figueiredo (Brasil)
Manoel de Oliveira Franco Sobrinho -
in memoriam (Brasil)
Marçal Justen Filho (Brasil)
Marcelo Figueiredo (Brasil)

\author{
Maria Cristina Cesar de Oliveira (Brasil) \\ Nelson Figueiredo (Brasil) \\ Odilon Borges Junior (Brasil) \\ Pascual Caiella (Argentina) \\ Paulo Eduardo Garrido Modesto (Brasil) \\ Paulo Henrique Blasi (Brasil) \\ Paulo Neves de Carvalho - in memoriam \\ (Brasil) \\ Paulo Ricardo Schier (Brasil) \\ Pedro Paulo de Almeida Dutra (Brasil) \\ Regina Maria Macedo Nery Ferrari (Brasil) \\ Rogério Gesta Leal (Brasil) \\ Rolando Pantoja Bauzá (Chile) \\ Sérgio Ferraz (Brasil) \\ Valmir Pontes Filho (Brasil) \\ Weida Zancaner (Brasil) \\ Yara Stropa (Brasil)
}

A246 A\&C Revista de Direito Administrativo \& Constitucional. ano 3, n. 11, jan./mar. 2003. Belo Horizonte: Fórum, 2003.

Trimestral

ano 1, n. 1, 1999 até ano 2, n. 10, 2002 publicada pela Editora Juruá em Curitiba

ISSN 1516-3210

1. Direito Administrativo. 2. Direito Constitucional. I. Fórum.

CDD: 342

CDU: 33.342

(C) 2008 Editora Fórum Ltda.

Todos os direitos reservados. É proibida a reprodução total ou parcial, de qualquer forma ou por qualquer meio eletrônico ou mecânico, inclusive através de processos xerográficos, de fotocópias ou de gravação, sem permissão por escrito do possuidor dos direitos de cópias (Lei nº 9.610, de 19.02.1998).

Editora Fórum Ltda

Editor responsável: Luís Cláudio Rodrigues Ferreira

Av. Afonso Pena, 2770 - 15\%16ªndar - Funcionários

CEP 30130-007 - Belo Horizonte/MG - Brasil

Coordenação editorial: Olga M. A. Sousa

Tel.: 08007043737

Internet: www.editoraforum.com.br

Pesquisa jurídica: Fátima Ribeiro - OAB/MG 74868

Revisora: Lourdes Nascimento

Projeto gráfico e diagramação: Luis Alberto Pimenta

e-mail: editoraforum@editoraforum.com.br

Bibliotecária: Fernanda de Paula Moreira - CRB 2900 - 6a região

Esta publicação está indexada no Ulrich's Periodicals Directory

Os conceitos e opiniões expressas nos trabalhos assinados são de responsabilidade exclusiva de seus autores.

Impressa no Brasil / Printed in Brazil

Distribuída em todo o Território Nacional 


\title{
O dogma da supremacia do interesse público e seu abrandamento pela jurisprudência do Supremo Tribunal Federal através da técnica da ponderação de princípios
}

\author{
Flávio Quinaud Pedron* \\ Mestre e doutorando em Direito pela UFMG. Professor de Teoria Geral do Processo e Direito \\ Processual na PUC-Minas. Coordenador do Núcleo de Prática Jurídica e do Serviço de Assistência \\ Jurídica (NPJ/SAJ) da PUC-Minas, Campus Serro. Advogado.
}

\begin{abstract}
Resumo: O presente trabalho pretende reconstruir a compreensão jurisprudencial do STF acerca da relação entre interesses públicos e interesses privado a fim de demonstrar como o primeiro não mais pode avocar primazia sobre o segundo. Tal conclusão, no direito brasileiro, foi obtida a partir do uso pelo Tribunal da técnica de "ponderação de princípios" de Robert Alexy, que também será analisada. Ao final, conclui-se leitura jurisprudencial, em razão do uso de tal técnica, não é uma via adequada ao Estado Democrático de Direito.
\end{abstract}

Palavras-chave: Supremacia do interesse público. Aplicação e conflito entre princípios. Legitimidade das decisões judiciais.

"Em que medida a Constituição de 1988 importa numa mudança na jurisprudência do Supremo Tribunal Federal? Em que medida as bases interpretativas no Supremo Tribunal Federal foram modificadas após a promulgação da Constituição de 1988?” Essas são as perguntas principais feitas por Baracho Júnior, ${ }^{1}$ em seu ensaio sobre a possibilidade de se identificar uma "nova hermenêutica" nos julgados do Supremo Tribunal Federal (STF).

Ora, se é possível identificar alguma forma de inovação, no curso da linha de raciocínio que o Tribunal vinha tomando, é de se pressupor também a existência de algo anterior, algo que foi ou está sendo superado. ${ }^{2}$

\footnotetext{
* Dedico este artigo à Professora Simone Reissinger pela interlocução, comunhão de projetos e pelo constante apoio.

BARACHO JÚNIOR. A nova hermenêutica na jurisprudência do Supremo Tribunal Federal. In: SAMPAIO (Coord.). Crise e desafios da Constituição: perspectivas críticas da teoria e das práticas constitucionais brasileiras, p. 509

2 Torna-se muito comum a afirmação de uma mudança hermenêutica no Direito brasileiro, ver, por exemplo, os trabalhos de Streck (A crise da hermenêutica e a hermenêutica da crise: a necessidade de uma nova crítica do direito) e Barroso e Barcelos (O começo da história: a nova interpretação constitucional e o papel dos princípios no direito brasileiro), que vêm desenvolvendo diversas pesquisas sobre o que seria essa "nova interpretação" assumida pelo Supremo Tribunal Federal em seus julgados.
}

A\&C R. de Dir. Administrativo \& Constitucional, Belo Horizonte, ano 8, n. 33, p. 193-217, jul./set. 2008 
Para tal empreitada, faz-se necessária a observância dos julgados não apenas como casos isolados, mas como "precedentes", ou seja, como fundamentos para as decisões seguintes — prática utilizada pelo STF para possivelmente representar uma forma de sistematizar a sua jurisprudência. ${ }^{3}$

Mas, diante da história institucional brasileira, esse trabalho pode se ver ameaçado: "Evidentemente que uma corte cujo trabalho é constantemente interrompido por golpes de Estado, tem maior dificuldade em consolidar uma orientação jurisprudencial minimamente coerente". ${ }^{4}$

O tema que pode funcionar como guia dessa tarefa, uma vez que sempre esteve presente, sendo tomado como um dogma, é a prevalência do interesse público sobre o interesse privado. Como lembra Ávila, ${ }^{5}$ para a dogmática jurídica, seu desenvolvimento teórico viria a partir dos estudos do Direito Administrativo, ${ }^{6}$ mas com ramificações e influências para outros "ramos" do Direito, como o direito tributário.

Se, por um lado, a discussão sobre a supremacia do interesse público sobre o privado era posta como um axioma ${ }^{7}$ - por partir das lições do

\footnotetext{
3 "Na Suprema Corte Americana é possível identificar nitidamente alguns períodos nos quais houve a consolidação de determinados princípios de interpretação constitucional, como o período de prevalência do devido processo substantivo, entre 1905 e 1937, o período da Corte de Warren, a partir de 1954, até 1969, que foi um período fortemente interventivo em relação às leis estaduais. Ou, ainda, a suprema Corte da Década de 1990, que é uma Suprema Corte fortemente preocupada com o princípio federativo e, por outro lado, abandona, em certa medida, os direitos fundamentais como principal foco de sua atuação, possibilitando que os Estados tenham maior liberdade de atuação legislativa em questões que importam em restrição ao exercício de tais direitos" (BARACHO JÚNIOR. A nova hermenêutica na jurisprudência do Supremo Tribunal Federal. In: SAMPAIO (Coord.). Crise e desafios da Constituição: perspectivas críticas da teoria e das práticas constitucionais brasileiras, p. 511).

4 BARACHO JÚNIOR. A nova hermenêutica na jurisprudência do Supremo Tribunal Federal. In: SAMPAIO (Coord.). Crise e desafios da Constituição: perspectivas críticas da teoria e das práticas constitucionais brasileiras, p. 510 .

5 ÁVILA. Repensando o "princípio da supremacia do interesse público sobre o particular". In: SARMENTO (Org.). Interesses públicos versus interesses privados: desconstruindo o princípio de supremacia do interesse público, p. 171.

6 Nesse sentido, encontra-se a lição de Bandeira de Mello (Curso de direito administrativo, p. 60): "Trata-se de verdadeiro axioma reconhecível no moderno Direito Público. Proclama a superioridade do interesse da coletividade, firmando a prevalência dele sobre o do particular, como condição, até mesmo da sobrevivência e asseguramento deste último". Todavia, nota-se que essa afirmação parte, ainda, de uma compreensão paradigmática do Direito que se olvida do atual paradigma procedimental do Estado Democrático de Direito. Como será explorado, no quarto capítulo, Habermas (Facticidad y Validez: sobre el derecho y el Estado democrático de derecho en términos de teoría del discurso) busca reconstruir os princípios do Estado de Direito e da Democracia para lançar uma compreensão não mais dicotômica da relação público/privado, mas, ao invés disso, eqüiprimordial. Para o filósofo alemão: "Os cidadãos só podem fazer um uso adequado de sua autonomia pública quando são independentes o bastante, em razão de uma autonomia privada que esteja equanimemente assegurada; mas também no fato de que só poderão chegar a uma regulamentação capaz de gerar consenso, se fizerem uso adequado de sua autonomia política enquanto cidadãos" (HABERMAS. A inclusão do outro: estudos de teoria política, p. 294).

7 Como lembra Ávila (Repensando o "princípio da supremacia do interesse público sobre o particular". In: SARMENTO, Daniel (Org.). Interesses públicos versus interesses privados: desconstruindo o princípio de supremacia do interesse público, p. 176): "Axioma (usado, originalmente, como sinônimo de postulado) denota uma proposição cuja veracidade é aceita por todos, dado que não é nem possível nem necessário prová-la. Por isso mesmo, são os axiomas aplicáveis exclusivamente por meio da lógica, e deduzidos sem a intervenção de pontos de vista materiais".
}

A\&C R. de Dir. Administrativo \& Constitucional, Belo Horizonte, ano 8, n. 33, p. 193-217, jul./set. 2008 
positivismo jurídico, que considerava a separação rígida entre Direito e Política, excluindo a possibilidade de um Tribunal apreciar "questões políticas" - por outro, tal afirmação também serviu como "forma de fragilizar a tutela de direitos individuais em face do poder público". ${ }^{8}$

Com isso, evitava a tutela de direitos individuais. E essa não era um debate novo no Supremo Tribunal Federal. Já no governo Floriano Peixoto, no início da República, logo após a implantação do Supremo Tribunal Federal, algumas questões que envolviam ofensas a direitos individuais não foram por ele apreciadas, pois, segundo dizia a Corte, eram questões políticas. Em 1893, em estado de sítio decretado por Floriano Peixoto, o Supremo se recusou a apreciar uma série de lesões a direitos individuais ao argumento de que aquelas questões eram políticas e que, portanto, não poderiam ser objeto de apreciação pelo Poder Judiciário. ${ }^{9}$

Entretanto, havia opositores a essa tese, como lembram Rodrigues ${ }^{10}$ e Souza Cruz. ${ }^{11}$ Segundo a historiadora, o discurso de Rui Barbosa, ${ }^{12}$ na defesa dos direitos individuais, representa um contraponto necessário ao exercício democrático dos direitos políticos:

\begin{abstract}
As palauras de Rui Barbosa em 1892 indicam essa concepção: "os casos, que, se por um lado toca a interesses políticos, por outro lado, envolvem direitos individuais, não podem ser defesos à intervenção dos tribunais, amparo de liberdade pessoal contra as invasões do executivo. [...] Onde quer que haja um direito individual violado, há de haver um recurso judicial para a debelação da injustiça. Quebrada a égide judiciária do direito individual, todos os diretos desaparecem, todas as autoridades se subvertem, a própria legislatura esfacela-se nas mãos da violência; só uma realidade subsiste: a onipotência do executivo, que a vós mesmos vos devorará, se nos desarmardes da vossa competência incontestável em todas as questões concernentes à liberdade.". ${ }^{13}$
\end{abstract}

Dessa forma, como afirma Souza Júnior, ${ }^{14}$ foi-se construindo a noção

\footnotetext{
8 BARACHO JÚNIOR. A nova hermenêutica na jurisprudência do Supremo Tribunal Federal. In: SAMPAIO (Coord.). Crise e desafios da Constituição: perspectivas críticas da teoria e das práticas constitucionais brasileiras, p. 513.

9 BARACHO JÚNIOR. A nova hermenêutica na jurisprudência do Supremo Tribunal Federal. In: SAMPAIO (Coord.). Crise e desafios da Constituição: perspectivas críticas da teoria e das práticas constitucionais brasileiras, p. 512-513.

10 RODRIGUES. História do Supremo Tribunal Federal: da defesa das liberdades civis, p. 20.

11 CRUZ. Jurisdição constitucional democrática, p. 277.

12 Como lembra Souza Júnior (SOUZA JúNIOR. O Supremo Tribunal Federal e as questões políticas, p. 89), a figura de Rui Barbosa foi determinante para o desenvolvimento do debate sobre as questões políticas, pois "[p]ropunha um diálogo franco entre os grandes poderes do Estado, estipulados em textos formais, de um lado, e, de outro, os direitos individuais, taxativamente assegurados. A interpretação judicial desempenha, neste diálogo, a missão de mediação com o objetivo de evitar as possíveis colisões. Se os poderes exercidos extrapolam o círculo de competências, ou se direitos individuais são feridos, a intervenção judicial é legítima. Se se quer debater a existência constitucional de uma faculdade administrativa ou legislativa, também o judiciário será o assunto".

13 RODRIGUES. História do Supremo Tribunal Federal: da defesa das liberdades civis, p. 20-21, grifos no original.

14 SOUZA JÚNIOR. O Supremo Tribunal Federal e as questões políticas, p. 88.
}

A\&C R. de Dir. Administrativo \& Constitucional, Belo Horizonte, ano 8, n. 33, p. 193-217, jul./set. 2008 
de que a condição para o exame judicial de questões políticas seria a possibilidade de lesão a direitos individuais.

Em um dos [julgados] mais antigos (HC 3061, julgado em 1911), o Supremo afirmou a possibilidade de conhecimento judicial do caso político quando acompanhado de uma questão judiciária. Logo depois, em 1914, aquela corte resguardou do exame judicial os motivos determinantes ou as conseqüências políticas dos atos de intervenção nos Estados. Construiu também o entendimento de que podia o Judiciário conhecer de casos puramente políticos, desde que se alegasse lesão de direito individual. ${ }^{15}$

Todavia, a noção de prevalência do interesse público sobre o interesse privado, mesmo com riscos à violação de direitos fundamentais, acaba se fortalecendo, principalmente a partir de 1960, intensificando-se no período autoritário que se seguiu.

Vamos ter, especialmente, a partir de 1965, com a edição do Ato Institucional n. 2, decisões do Supremo Tribunal Federal que importam em negar tutela de uma série de direitos individuais, fortalecendo a idéia de prevalência do interesse público sobre o privado. É o que vamos ver em algumas decisões, como por exemplo, no caso João Goulart, em 1967. De uma maneira geral, as questões que envolviam a segurança nacional, se pautavam pela idéia de prevalência do interesse público sobre o privado. ${ }^{16}$

Essa interpretação permaneceu, contudo, com o advento da Constituição da República de 1988; como afirma Baracho Júnior, ${ }^{17}$ basta analisar a decisão proferida na $\mathrm{ADI} \mathrm{n}^{\circ}$ 47, que tratou da interpretação do art. 100 da Carta Magna, estabelecendo que "à exceção dos créditos de natureza alimentícia, a execução contra a fazenda pública se fará através de precatório". ${ }^{18}$

De uma maneira geral, para os publicistas, mas principalmente para os administrativistas, o princípio da supremacia do interesse público sobre

\footnotetext{
15 SOUZA JÚNIOR. O Supremo Tribunal Federal e as questões políticas, p. 88.

16 BARACHO JÚNIOR. A nova hermenêutica na jurisprudência do Supremo Tribunal Federal. In: SAMPAIO (Coord.). Crise e desafios da Constituição: perspectivas críticas da teoria e das práticas constitucionais brasileiras, p. 514.

17 BARACHO JÚNIOR. A nova hermenêutica na jurisprudência do Supremo Tribunal Federal. In: SAMPAIO (Coord.). Crise e desafios da Constituição: perspectivas críticas da teoria e das práticas constitucionais brasileiras, p. 514.

18 Lembra Baracho Júnior (A nova hermenêutica na jurisprudência do Supremo Tribunal Federal, p. 514-515): "Nesta [ADI], o Supremo Tribunal Federal interpretou o art. 100 de uma maneira que contraria os próprios anais da Assembléia Nacional Constituinte. O Constituinte pretendeu retirar os créditos de natura alimentícia desta forma de execução, qual seja, a execução através de precatórios. O Supremo Tribunal Federal, entretanto, afirmou que a única especificidade que decore do art. 100 da Constituição é a possibilidade dos créditos de natureza alimentícia terem prioridade em relação a outros créditos contra a fazenda pública. Assim, os créditos alimentícios terão sempre prioridade na ordem de pagamento em relação a outros créditos".
}

A\&C R. de Dir. Administrativo \& Constitucional, Belo Horizonte, ano 8, n. 33, p. 193-217, jul./set. 2008 
o particular se apresenta como um princípio implícito na ordem jurídica brasileira e seria usado para justificar uma série de prerrogativas titularizadas pela Administração Pública. Isso ocorre por se entender que a mesma seria a "tutora" e a "guardiã dos interesses da coletividade". ${ }^{19}$ Como conseqüência, verifica-se a existência de uma verticalidade na relação entre a Administração Pública e os administrados, de modo que o desequilíbrio seria sempre em favor do Estado.

Mas o que se pode considerar como interesse público? Talvez essa questão devesse ser mais bem problematizada pelos publicistas, que muitas vezes igualam a dimensão do público à coletividade e, outras vezes, ao estatal (governamental).

Para Bandeira de Mello, ${ }^{20}$ valendo-se das lições de Alessi, ${ }^{21}$ seria possível distinguir dois tipos de interesse público: interesse público primário e interesse público secundário. ${ }^{22}$ Nessa ótica, identifica-se o interesse primário como sendo a razão de ser do Estado ou como os interesses gerais da coletividade; já o segundo tipo representa os interesses particulares que o Estado possui como pessoa jurídica e não mais como expressão de uma vontade coletiva. Logo, alguns administrativistas buscam fazer uma ponte entre o interesse público primário e o bem comum como forma de afirmação de sua superioridade em face do interesse privado.

Binenbojm ${ }^{23}$ faz uma crítica precisa à tentativa de alguns juristas de justificar a supremacia do interesse público como princípio norteador da ação administrativa. Nesse sentido, a supremacia do interesse público atuaria como garantia de proteção, inclusive do interesse privado, já que impediria o Estado de atuar a favor de interesses privatísticos, desviandose dos fins coletivos. Todavia, a corrente a que se filia Di Pietro ${ }^{24}$ nada esclarece sobre a relação público/privado; além do mais, os problemas por

\footnotetext{
19 SARMENTO. Interesses públicos vs. Interesses privados na perspectiva da Teoria e da Filosofia Constitucional. In: SARMENTO (Org.). Interesses públicos versus interesses privados: desconstruindo o princípio de supremacia do interesse público, p. 24.

20 BANDEIRA DE MELLO. Curso de direito administrativo, p. 57

${ }^{21}$ Sistema Istituzionale del diritto amministrativo ilaliano, 1960, p. 197, apud BANDEIRA DE MELLO (Curso de direito administrativo, p. 57).

22 SARMENTO. Interesses públicos vs. Interesses privados na perspectiva da Teoria e da Filosofia Constitucional. In: SARMENTO (Org.). Interesses públicos versus interesses privados: desconstruindo o princípio de supremacia do interesse público, p. 24; BARROSO. O Estado contemporâneo, os direitos fundamentais e a redefinição da supremacia do interesse público. In: SARMENTO (Org.). Interesses públicos versus interesses privados: desconstruindo o princípio de supremacia do interesse público, p. xiii.

23 BINENBOJM. Da supremacia do interesse público ao dever de proporcionalidade: um novo paradigma para o direito administrativo. In: SARMENTO (Org.). Interesses públicos versus interesses privados: desconstruindo o princípio de supremacia do interesse público, p. 137.

${ }^{24}$ DI PIETRO. Direito administrativo, p. 69-70.
}

A\&C R. de Dir. Administrativo \& Constitucional, Belo Horizonte, ano 8, n. 33, p. 193-217, jul./set. 2008 
ela apontados não são resolvidos nesse plano, mas no plano dos princípios da impessoalidade e da moralidade.

Salles, ${ }^{25}$ por sua vez, reconhece a dificuldade de se chegar a um conceito de fácil assimilação, haja vista a natureza genérica que o conceito deve assumir para abranger uma pluralidade de interesses dispersos pela sociedade. Dessa forma, vale-se do Teorema de Arrow (Arrow's theorem) ${ }^{26}$ para assegurar que tomadas de posição que parecem envolver uma discricionariedade, seria melhor, se deixadas a cargo da decisão estatal (política), representativa do interesse público. Todavia, tal posição pode parecer por demais cética e, até mesmo, ingênua - por vezes, autoritária - ao imaginar que o Estado seja capaz de corporificar todos os anseios e desejos de uma sociedade. Além do mais, vale aqui o alerta de Sarmento, ${ }^{27}$ já que tal tese pode representar uma forma de ressurreição das "razões de Estado", colocando-se como obstáculo intransponível para o exercício de direitos fundamentais. ${ }^{28}$

A outra proposta que identifica o público ao componente majoritário também se mostra delicada. Tomando como referência aplicada dessa concepção a decisão proferida no julgamento do Recurso Extraordinário no 153.531-8, de Santa Catarina, fica claro que o interesse público aqui é igualado a uma maioria da sociedade. Ao examinar o questionamento de se a farra do boi — prática de alguns descendentes de açorianos residentes em Florianópolis - representaria um risco para a segurança dos participantes e uma ação cruel para com os animais, Baracho Júnior afirma que:

O Supremo Tribunal Federal trabalha com dois fundamentos para dizer que o Estado de Santa Catarina deveria atuar, através da Polícia Militar, no sentido de reprimir a farra do boi. O primeiro argumento é que os animais estariam

\footnotetext{
${ }_{25}$ SALLES. Processo civil de interesse público. In: SALLES (Org.). Processo civil e interesse público: o processo como instrumento de defesa social, p. 58.

${ }^{26}$ Segundo Salles (Processo civil de interesse público, p. 59), Kenneth J. Arrow "demonstrou [seu teorema] no começo da década de 60. Arrow tomou hipoteticamente três indivíduos com poder para tomar uma decisão e, considerando que cada um deles tem uma ordem de preferências diferentes, demonstrou, matematicamente, que o cruzamento dessas preferências individuais pode levar a decisões inteiramente aleatórias, dependendo de fatores estruturais do processo decisório".

27 SARMENTO. Interesses públicos vs. Interesses privados na perspectiva da Teoria e da Filosofia Constitucional. In: SARMENTO (Org.). Interesses públicos versus interesses privados: desconstruindo o princípio de supremacia do interesse público, p. 27.

28 Aragão (A "supremacia do interesse público" no advento do Estado de Direito e na hermenêutica do direito público contemporâneo, p. 7) alerta para o risco de que supostos "interesses públicos" sejam utilizados pelo Estado como forma de justificar restrições aos direitos fundamentais. Cita, para tanto, dois precedentes norte-americanos: no primeiro, Dennis vs. United States, esse dogma possibilitou restrições à liberdade de manifestação de idéias que fossem consideradas esquerdistas; no outro, Korematsu vs. United States, permitiu que cidadãos norte-americanos de origem japonesa ficassem confinados em campos de concentração durante a Segunda Guerra Mundial.
}

A\&C R. de Dir. Administrativo \& Constitucional, Belo Horizonte, ano 8, n. 33, p. 193-217, jul./set. 2008 
submetidos à crueldade. O art. 225 da Constituição, inciso VII, diz que o Estado não deverá tolerar crueldades contra animais. O segundo fundamento é o mais curioso desta decisão, porque é exatamente a prevalência de uma visão majoritária sobre a de uma coletividade [minoritária]. Há uma idéia de que as tradições de um grupo minoritário não podem prevalecer sobre as tradições que não são compartilhadas pela maioria da sociedade brasileira. As expressões utilizadas no voto vencedor são ilustrativas, pois os descendentes de açoreanos são comparados a uma "turba ensandecida" que adota procedimentos estarrecedores. ${ }^{29}$

Dessa forma, o Supremo Tribunal Federal deixou de observar a dimensão hermenêutica envolvida na questão. Tomando apenas a posição de um observador sociológico, compreendeu-se que o interesse público aqui seria o de proteger os animais de uma prática violenta. Todavia,

[...] esta idéia de violência não existe para os açoreanos. Os descendentes de açoreanos que faziam da farra do boi uma celebração anual, não associavam à manifestação uma idéia de violência que nós, que não somos descendentes de açoreanos, associamos. Este é um dado importante, pois, na Espanha, por exemplo, em práticas semelhantes, a idéia de violência não está associada. Dificilmente tais práticas seriam atribuídas a uma "turba ensandecida" na Espanha. Muito menos seriam os procedimentos considerados como estarrecedores. ${ }^{30}$

Dessa forma, pode-se perceber que a associação do interesse público ao interesse de uma maioria da sociedade mostra-se insuficiente sob o prisma de uma democracia pluralista, que garante a inclusão da perspectiva de todos os envolvidos.

Logo, definir o interesse público como interesse geral de uma coletividade e contrapô-lo a um interesse privado limitado ao perímetro das vivências experimentadas pelos indivíduos fora do alcance da polis ${ }^{31}$ é insuficiente. Primeiro, porque não pode o indivíduo ignorar a dimensão imposta pela vida em sociedade; sua casa não pode servir como metáfora da ilha imaginada por Crusoé, ou ser entendida como uma fortaleza que coloque o público na porta da rua; pois o processo de socialização acontece

\footnotetext{
${ }^{29}$ BARACHO JÚNIOR. A nova hermenêutica na jurisprudência do Supremo Tribunal Federal. In: SAMPAIO (Coord.). Crise e desafios da Constituição: perspectivas críticas da teoria e das práticas constitucionais brasileiras, p. 516.

30 BARACHO JÚNIOR. A nova hermenêutica na jurisprudência do Supremo Tribunal Federal. In: SAMPAIO (Coord.). Crise e desafios da Constituição: perspectivas críticas da teoria e das práticas constitucionais brasileiras, p. 517.

31 SARMENTO. Interesses públicos vs. Interesses privados na perspectiva da Teoria e da Filosofia Constitucional. In: SARMENTO (Org.). Interesses públicos versus interesses privados: desconstruindo o princípio de supremacia do interesse público, p. 30.
}

A\&C R. de Dir. Administrativo \& Constitucional, Belo Horizonte, ano 8, n. 33, p. 193-217, jul./set. 2008 
concomitantemente com o processo de individualização. ${ }^{32}$ Sarmento $^{33}$ lembra que a sociedade contemporânea é por demais complexa para se apoiar em pilares estanques. Vive-se em um tempo que imprime um novo sentido à concepção de espaço público, que não vem mais associada unicamente ao elemento estatal. ${ }^{34}$

A pergunta sobre qual é o interesse da coletividade leva, então, a uma outra pergunta: quem é a coletividade?, ou a outra ainda mais radical: “quem é o povo?", que já suscitou um importante ensaio pelo jurista alemão Müller. ${ }^{35}$ Nesse trabalho, Müller alerta para a figura do povo como um ícone - em igual precisão, Carvalho Netto ${ }^{36}$ lembra que o conceito de povo é por demais "gordo", isto é, pode ser manipulado ao sabor de conveniências políticas.

Outro importante trabalho é o texto de Rosenfeld sobre a Identidade do sujeito constitucional. ${ }^{37}$ Através das reflexões do professor da Cardozo School of Law, pode-se compreender o conceito de povo como um eterno hiato, aberto a um processo dinâmico de elaboração e revisão. É justamente no seu fechamento como conceito que se encontra o perigo para a democracia:

Esse rápido olhar inicial sobre a identidade constitucional, bem como sobre o sujeito e a matéria constitucionais revela que é bem mais fácil determinar o que eles não são do que propriamente o que eles são. Ao construir essa intuição, esse insight, exploro a tese segundo a qual, em última instância, é preferível e mais acurado considerar o sujeito e a matéria constitucionais como uma ausência mais do que como uma presença. Em outros termos, a própria questão do sujeito e da matéria constitucionais é estimulante porque encontramos um hiato, um vazio, no lugar em que buscamos uma fonte última de legitimidade e autoridade para a ordem constitucional. Além do mais, o sujeito constitucional deve ser considerado como um hiato ou uma ausência em pelo menos dois sentidos distintos: primeiramente, a ausência do sujeito constitucional não

\footnotetext{
32 Ver HABERMAS. Pensamento pós-metafísico: estudos filosóficos; HABERMAS. Teoría de la acción comunicativa; e FERREIRA. Individualização e socialização em Jürgen Habermas: um estudo sobre a formação discursiva da vontade.

33 SARMENTO. Interesses públicos vs. Interesses privados na perspectiva da Teoria e da Filosofia Constitucional. In: SARMENTO (Org.). Interesses públicos versus interesses privados: desconstruindo o princípio de supremacia do interesse público, p. 47.

34 "De fato, se no Estado Liberal o público correspondia ao Estado e o privado a uma sociedade civil regida pelo mercado, considerada como o locus em que indivíduos perseguiam egoisticamente seus interesses particulares, robustece-se agora um terceiro setor, que é público, mas não estatal. Ele é composto por ONGs, associações de moradores, entidades de classe e outros movimentos sociais, que atuam em prol de interesses da coletividade, e agem aglutinando e canalizando para o sistema político demandas importantes, muitas vezes negligenciadas pelas instâncias representativas tradicionais" (SARMENTO, 2005, p. 48).

35 MÜLLER. Quem é o povo?: a questão fundamental da democracia.

36 CARVALHO NETTO. Racionalização do ordenamento jurídico e democracia. Revista brasileira de estudos políticos, p. 84.

37 ROSENFELD. A identidade do sujeito constitucional.
}

A\&C R. de Dir. Administrativo \& Constitucional, Belo Horizonte, ano 8, n. 33, p. 193-217, jul./set. 2008 
nega o seu caráter indispensável, daí a necessidade de sua reconstrução; e, em segundo lugar, o sujeito constitucional sempre envolve um hiato porque ele é inerentemente incompleto, e então sempre aberto a uma necessária, mas impossível, busca de completude. Conseqüentemente, o sujeito constitucional encontra-se constantemente carente de reconstrução, mas essa reconstrução jamais pode se tornar definitiva ou completa. Da mesma forma, de modo consistente com essa tese, a identidade constitucional deve ser reconstruída em oposição às outras identidades, na medida em que ela não pode sobreviver a não ser que pertença distinta dessas últimas. Por outro lado, a identidade constitucional não pode simplesmente dispor dessas outras identidades, devendo então lutar para incorporar e transformar alguns elementos tomados de empréstimo. Em suma, a identidade do sujeito constitucional só é suscetível de determinação parcial mediante um processo de reconstrução orientado no sentido de alcançar um equilíbrio entre a assimilação e a rejeição das demais identidades relevantes acima discutidas. ${ }^{38}$

Para isso, Rosenfeld utiliza três instrumentos teóricos:

A negação, a metáfora e a metonímia combinam-se para selecionar, descartar e organizar os elementos pertinentes com vistas a produzir um discurso constitucional no e pelo qual o sujeito constitucional possa fundar sua identidade. A negação é crucial à medida que o sujeito constitucional só pode emergir como um "eu" distinto por meio da exclusão e da renúncia. A metáfora ou condensação, por outro lado, que atua mediante o procedimento de se destacar as semelhanças em detrimento das diferenças, exerce um papel unificador chave ao produzir identidades parciais em torno das quais a identidade constitucional possa transitar. A metonímia ou deslocamento, finalmente, com a sua ênfase na contigüidade e no contexto, é essencial para evitar que o sujeito constitucional se fixe em identidades que permaneçam tão condensadas e abstratas ao ponto de aplainar as diferenças que devem ser levadas em conta se a identidade constitucional deve realmente envolver tanto o eu quanto o outro. ${ }^{39}$

Dessa forma, dentro de uma mesma sociedade, há não apenas uma identidade coletiva, mas diversas e até mesmo concorrentes, de modo que uma interpretação da Constituição que leve em conta apenas uma identidade, por mais majoritária que seja, pode lançar complicações para o desenvolvimento da democracia. Afinal a identidade constitucional, embora aberta às diversas identidades coletivas, não se confunde com nenhuma delas.

Todavia, como o próprio julgamento do Recurso Extraordinário $\mathrm{n}^{\mathrm{o}}$ 153.531-8 irá revelar, a noção de interesse público não foi tomada como

\footnotetext{
${ }^{38}$ ROSENFELD. A identidade do sujeito constitucional, p. 26-27.

${ }^{39}$ ROSENFELD. A identidade do sujeito constitucional, p. 50.
}

A\&C R. de Dir. Administrativo \& Constitucional, Belo Horizonte, ano 8, n. 33, p. 193-217, jul./set. 2008 
um dogma, mas sim compreendida de maneira a ter de se "compatibilizar" com o interesse privado pela via da utilização. Para tanto, conforme inspiração no Direito alemão, mais exatamente na tradição da jurisprudência de valores alemã, o STF fez uso da técnica de ponderação, por meio da qual: "[...] Quanto maior o grau de não satisfação ou de afetação de um princípio, tanto mais tem que ser a importância da satisfação do outro" (tradução livre) ${ }^{40}$

Como observa Souza Cruz, ${ }^{41}$ o pensamento utilitarista serve de base para a ponderação; ${ }^{42}$ todavia seus defensores alegam que o "princípio" da proporcionalidade seria capaz de impedir a escolha arbitrária, vinculando o operador jurídico ao uso de meios adequados e proporcionais. Um desses defensores é o jurista de Kiel, Alexy. Mas, como se verificará, o presente trabalho irá sustentar a tese de que, no pensamento de Alexy, ainda persiste uma dificuldade em assimilar completamente o giro hermenêuticopragmático, ${ }^{43}$ por ainda buscar no método ${ }^{44}$ a expressão de uma racionalidade capaz de neutralizar toda a complexidade inerente à linguagem. ${ }^{45}$

40 "[...] Cuanto mayor es el grado de la no satisfacción o de afectación de un principio, tanto mayor tiene que ser la importancia de la satisfacción del otro" (ALEXY. Teoría de los Derechos Fundamentales, p. 161).

${ }^{41}$ CRUZ. Jurisdição constitucional democrática, p. 160.

42 A popularidade do método da ponderação adquire cada dia mais destaque nos julgamentos proferidos pelo Supremo Tribunal Federal brasileiro (STF). Tanto assim, que Barroso e Barcelos (O Começo da história: a nova interpretação constitucional e o papel dos princípios no direito brasileiro, p. 471) e Baracho Júnior (BARACHO JÚNIOR. A nova hermenêutica na jurisprudência do Supremo Tribunal Federal. In: SAMPAIO (Coord.). Crise e desafios da Constituição: perspectivas críticas da teoria e das práticas constitucionais brasileiras, p. 520) defendem que sua adoção representa uma mudança no curso da interpretação levada a cabo pelo tribunal, equivalendo à adoção de uma Nova Hermenêutica na Jurisprudência do STF. O precedente representado pelo HC no 82.424/RS mostra-se como exemplo de uma aplicação prática da teoria de Alexy. Isso porque o caso ganhou notoriedade por examinar um suposto conflito entre os princípios da liberdade de expressão e da dignidade da pessoa humana, envolvendo a acusação de prática de racismo durante a publicação de livros anti-semitas. As bases da ponderação foram bem explicitadas através dos votos dos Ministros Gilmar Mendes e Marco Aurélio.

${ }^{43}$ Cabe destacar, desde já, que, diferentemente de Alexy, Dworkin desenvolve sua teoria levando em conta o giro hermenêutico empreendido por Heidegger e Gadamer, sendo que o último irá adotar uma postura de ruptura com as posições objetivistas de Schleiermacher e Dilthey, radicalizando a experiência hermenêutica e se apoiando principalmente no modo de ser do Dasein (do ser-aí) heideggeriano. Desta forma, a Hermenêutica Filosófica entende que "a compreensão humana se orienta a partir de uma pré-compreensão que emerge da eventual situação existencial e que demarca o enquadramento temático e o limite de validade de cada tentativa de interpretação" (GRONDIN. Introdução à hermenêutica filosófica, p. 159). Os reflexos da percepção de tal "consciência histórica" podem ser sentidos no pensamento de Dworkin, como lembra Carvalho Netto: "Para ele, a unicidade e a irrepetibilidade que caracterizam todos os eventos históricos, ou seja, também qualquer caso concreto sobre o qual se pretenda tutela jurisdicional, exigem do juiz hercúleo esforço no sentido de encontrar no ordenamento considerado em sua inteireza a única decisão correta para este caso específico irrepetível por definição" (Requisitos pragmáticos da interpretação jurídica sob o paradigma do Estado Democrático de Direito. Revista de Direito Comparado, p. 475).

${ }^{44}$ ALEXY. Derecho y Razón Práctica, p. 32; ALEXY. Constitutional Rights, Balancing and Rationality. Ratio Júris, p. 139; ALEXY. Teoría de los Derechos Fundamentales, p. 98.

45 Importante lembrar a colocação de Cattoni de Oliveira (Direito processual constitucional, p. 77-78) no sentido de que, para Alexy (Teoria da Argumentação Jurídica, p. 17-18), a racionalidade de um discurso prático pode ser mantida se forem satisfeitas as condições expressas por um sistema de regras ou procedimentos.

A\&C R. de Dir. Administrativo \& Constitucional, Belo Horizonte, ano 8, n. 33, p. 193-217, jul./set. 2008 
A partir dessa ótica, tanto o interesse público quanto o interesse privado podem ser considerados à luz de princípios. Alexy ${ }^{46}$ concorda com a compreensão de regras e de princípios como espécies de normas jurídicas - o que leva à necessidade de empreender uma digressão sobre uma compreensão do Direito para além de um mero conjunto de regras. ${ }^{47}$

Partindo dessa premissa, lembra-se que freqüentemente a distinção entre ambos os standars normativos se dá em razão da generalidade dos princípios frente às regras. Isto é, muitos autores compreendem os princípios como normas de um grau de generalidade relativamente alta, ao passo que as regras seriam dotadas de uma menor generalidade. ${ }^{48}$ Contudo, tal abordagem quantitativa, levada adiante por autores como Del Vecchio e Bobbio, mostra-se insuficiente à luz do pensamento desenvolvido já em Esser ${ }^{49}$ como demonstra Galuppo. ${ }^{50}$

Tal tese é denominada por Alexy ${ }^{51}$ como a tese fraca da separação, de modo que uma tese forte, como a que o autor pretende adotar, considera a distinção como qualitativa. Logo, pode-se perceber que a generalidade não é um critério adequado para tal distinção, pois é, quando muito, uma conseqüência da natureza dos princípios, sendo incapaz de proporcionar uma diferenciação essencial. ${ }^{52}$

Afirma-se, então, que regras, diferentemente dos princípios, são aplicáveis na maneira do tudo-ou-nada (all-or-nothing-fashion) ; 53 isso significa dizer que, se uma regra é válida, ela deve ser aplicada da maneira

\footnotetext{
46 ALEXY. Derecho y Razón Práctica, p. 09.

47 Aqui é preciso lembrar que Alexy toma como referência de norma o conceito "semântico" de norma (GALUPPO. Princípios jurídicos e a solução de seus conflitos: uma contribuição da obra de Alexy. Revista da Faculdade Mineira de Direito, p. 135-136) presente já em Kelsen (Teoria pura do direito), de modo que compreende que a norma é o significado extraído de um enunciado.

48 Nesse sentido, ver Hart (O conceito de direito, p. 321-325) em resposta a distinção dworkiana entre princípios e regras.

49 "Para Josef Esser, princípios são aquelas normas que estabelecem fundamentos para que determinado mandamento seja encontrado. Mais do que uma distinção baseada no grau de abstração da prescrição normativa, a diferença entre os princípios e as regras seria uma distinção qualitativa. O critério distintivo dos princípios em relação às regras seria, portanto, a função de fundamento normativo para a tomada de decisão" (ÁVILA. Teoria dos princípios: da definição à aplicação dos princípios jurídicos, p. 27).

50 GALUPPO. Igualdade e diferença: Estado Democrático de Direito a partir do pensamento de Habermas, p. 170-171.

51 ALEXY. Derecho y Razón Práctica, p. 09.

52 GALUPPO. Princípios jurídicos e a solução de seus conflitos: uma contribuição da obra de Alexy. Revista da Faculdade Mineira de Direito, p. 137.

53 Muitos autores atribuem a Alexy a originalidade da distinção entre regras e princípios; todavia, esses se olvidam do importante ensaio publicado por Dworkin, Model of Rules, originalmente, na Chicago Law Review, n. 35 (1967-1968), sendo, depois, republicado como o capítulo 2 da obra Levando os direitos a sério (com tradução para o português pela Editora Martins Fontes, em 2002). Todavia, importante lembrar, mais uma vez, que a distinção dworkiana se pauta pelo prisma lógico-argumentativo, e não por critérios estruturais - ou morfológicos —. Reconhecendo isso, tem-se Sarmento (A ponderação de interesses na Constituição Federal, p. 44).
} 
como preceitua, nem mais nem menos, conforme um procedimento de subsunção silogístico. ${ }^{54}$

Todavia, o principal traço distintivo com relação aos princípios é observado quando, diante de um conflito entre regras, algumas posturas deverão ser tomadas para que apenas uma delas seja considerada válida. ${ }^{55}$ Como conseqüência, a outra regra não somente não será considerada pela decisão, mas deverá ser retirada do ordenamento jurídico, como inválida, salvo se não for estabelecido que essa regra se situa em uma situação que excepciona a outra - trata-se do critério da excepcionalidade das regras.

Um exemplo é fornecido pelo próprio Alexy: ${ }^{56}$ uma Lei Estadual proibia o funcionamento de estabelecimentos comerciais após as 13 horas e, concomitantemente, existia uma Lei Federal estendendo esse funcionamento até as 19 horas. Nesse caso, o Tribunal Constitucional alemão solucionou a controvérsia, apoiando-se no cânone da hierarquia das normas, de modo a entender pela validade da legislação federal.

Já os princípios, por sua vez, não são determinantes para uma decisão, de modo que somente apresentariam razões em favor de uma ou de outra posição argumentativa; ${ }^{57} \operatorname{logo}$ apresentam obrigações prima facie, na medida em que podem ser superadas em função de outros princípios, ${ }^{58} \mathrm{O}$ que difere na natureza de obrigações absolutas das regras. É, por isso, que o autor afirma existir uma dimensão de peso entre princípios - que permanece inexistente nas regras - principalmente nos chamados casos de colisão, exigindo para a sua aplicação um procedimento de ponderação (balanceamento).

Destarte, em face de uma colisão entre princípios, o valor decisório será dado a um princípio que tenha, naquele caso concreto, maior peso relativo, sem que isso signifique a invalidação do princípio compreendido como de peso menor. Em face de outro caso, portanto, o peso dos princípios poderá ser redistribuído de maneira diversa, ${ }^{59}$ pois nenhum princípio

\footnotetext{
54 SILVA. O proporcional e o razoável. Revista dos Tribunais, p. 25.

55 ÁVILA. Teoria dos princípios: da definição à aplicação dos princípios jurídicos, p. 30.

${ }^{56}$ ALEXY. El concepto y la validez del derecho, p. 163-164.

57 ALEXY. Derecho y Razón Práctica, p. 09-10.

58 ÁVILA. Teoria dos princípios: da definição à aplicação dos princípios jurídicos, p. 30; SILVA. A constitucionalização do direito: os direitos fundamentais nas relações entre particulares, p. 32.

59 "No caso das colisões entre princípios, portanto, não há como se falar em um princípio que sempre tenha precedência em relação a outro. [...] É por isso que não se pode falar que um princípio $P 1$ sempre prevalecerá sobre o princípio $P 2$ - (P1 P P2) -, devendo-se sempre falar em prevalência do princípio $P 1$ sobre o princípio $P 2$ diante das condições $C$ - (P1 P P2) C" (SILVA. A constitucionalização do direito: os direitos fundamentais nas relações entre particulares, p. 35).
}

A\&C R. de Dir. Administrativo \& Constitucional, Belo Horizonte, ano 8, n. 33, p. 193-217, jul./set. 2008 
goza antecipadamente de primazia sobre os demais. ${ }^{60}$ É desta forma que Alexy $^{61}$ apresenta a distinção fundamental entre regras e princípios:

[...] princípios são normas que ordenam que algo se realize na maior medida possível, em relação às possibilidades jurídicas e fáticas. Os princípios são, por conseguinte, mandamentos de otimização que se caracterizam porque podem ser cumpridos em diferentes graus e porque a medida de seu cumprimento não só depende das possibilidades fáticas, mas também das possibilidades jurídicas. [...]. Por outro lado, as regras são normas que exigem um cumprimento pleno e, nessa medida, podem sempre ser somente cumpridas ou não. Se uma regra é válida, então é obrigatório fazer precisamente o que se ordena, nem mais nem menos. As regras contêm por isso determinações no campo do possível fático e juridicamente. ${ }^{62}$

Mas como explicar a natureza de mandamentos de otimização $0^{63}$ atribuída aos princípios? Ou de outra forma, como uma norma pode ter sua aplicação em diferentes graus? Para Alexy, ${ }^{64}$ isso pode ser explicado quando se compreende que princípios podem ser equiparados a valores. Uma concepção sobre valores — isto é, axiológica — dirá Alexy, ${ }^{65}$ traz uma referência não no nível do dever-ser (deontológico), mas no nível do que pode ou não ser considerado como bem. Os valores têm como características a possibilidade de valoração, isto é, permitem que um determinado juízo possa ser classificado, comparado ou medido. Destarte,

Com a ajuda de conceitos de valor classificatório se pode dizer que algo tem um valor positivo, negativo ou neutro; com a ajuda de conceitos de valor

\footnotetext{
${ }^{60}$ Isso pode ser percebido no julgamento do HC n 82.424/RS. Como já comentado, o STF identificou um conflito envolvendo os princípios da dignidade da pessoa humana e da liberdade de expressão. Em momento algum, afirmou-se que a dignidade da pessoa humana (ou mais exatamente, não discriminação) seria hierarquicamente superior à liberdade de expressão. Assim, um ou outro princípio pode ser ponderado através de sua aplicação gradual no caso sub judice. Assim, como bem reconhece o Min. Marco Aurélio em seu voto, "as colisões entre princípio [sob essa ótica] somente podem ser superadas se algum tipo de restrição ou de sacrifício formem impostos a um ou os dois lados. Enquanto o conflito entre regras resolvese na dimensão da validade, [...] o choque de princípios encontra solução na dimensão do valor, a partir do critério da 'ponderação', que possibilita um meio-termo entre a vinculação e a flexibilidade dos direitos".

61 ALEXY. Derecho y Razón Práctica, p. 12.

62 " [...] principios son normas que ordenan que se realice algo en la mayor medida posible, en relación con las posibilidades jurídicas y fácticas. Los principios son, por consiguiente, mandatos de optimización que se caracterizan por que pueden ser cumplidos en diversos grados y porque la medida ordenada de su cumplimiento no sólo depende de las posibilidades fácticas, sino también de las posibilidades jurídicas. [...] En cambio, las reglas son normas que exigen un cumplimiento pleno y, en esa medida, pueden siempre ser sólo o cumplidas o incumplidas. Si una regla es válida, entonces es obligatorio hacer precisamente lo que ordena, ni más ni menos. Las reglas contienen por ello determinaciones en el campo de lo posible fáctica y jurídicamente" (ALEXY. Derecho y Razón Práctica, p. 12, grifos no original, tradução livre).

63 Afonso da Silva (O proporcional e o razoável, p. 25) alerta que, devido à influência das traduções espanholas das obras de Alexy, tornou-se comum referir-se aos princípios como "mandados de otimização". Todavia, trata-se de utilização imprópria, preferindo esse autor o termo mandamentos de otimização.

${ }^{64}$ ALEXY. Derecho y Razón Práctica, p. 14; ALEXY. Teoría de los Derechos Fundamentales, p. 138.

65 ALEXY. Teoría de los Derechos Fundamentales, p. 139.
}

A\&C R. de Dir. Administrativo \& Constitucional, Belo Horizonte, ano 8, n. 33, p. 193-217, jul./set. 2008 
comparativo, que a um objeto que se deve valorar corresponde um valor maior ou o mesmo valor que outro objeto e, com ajuda de conceitos de valor métrico, que algo tem um valor de determinada magnitude. ${ }^{66}$

Todavia, apesar de dizer que princípios podem ser equipados aos valores, Alexy ${ }^{67}$ dirá que princípios não são valores. Isso porque os princípios, como normas, apontam para o que se considera devido, ao passo que os valores apontam para o que pode ser considerado melhor. ${ }^{68}$ Assim, mesmo tendo uma operacionalização idêntica aos valores, ainda assim princípios apresentam uma diferença básica frente aos valores. ${ }^{69}$

Para concluir, dirá que, se alguém estiver diante de uma norma que exige um cumprimento na maior medida do possível, estará diante de um princípio; em contrapartida, se tal norma exigir apenas o cumprimento em uma determinada medida, ter-se-á uma regra. Logo, a diferença se centraria em um aspecto da estrutura dos princípios e das regras, de uma maneira morfológica, fazendo com que regras sejam aplicadas de maneira silogística e princípios, por meio de uma ponderação ou balanceamento. ${ }^{70}$

Dessa forma, os princípios que prescrevem a proteção tanto do interesse público de um lado quanto do interesse privado de outro deverão ser ponderados por meio do "princípio" da proporcionalidade, ${ }^{71}$ para que se possa atingir um resultado em face de um caso concreto.

\footnotetext{
66 "Con la ayuda de conceptos de valor clasificatorios se puede decir que algo tiene un valor positivo, negativo o neutral; con la ayuda de conceptos de valor comparativos, que a un objeto que hay que valorar le corresponde un valor o el mismo valor que a otro objeto y, con la ayuda de conceptos de valor métricos, que algo tiene un valor de determinada magnitud" (ALEXY. Teoría de los Derechos Fundamentales, p. 143, tradução livre).

${ }_{67}$ ALEXY. Teoría de los Derechos Fundamentales, p. 147.

68 "La diferencia entre principios y valores se reduce así a un punto. Lo que en el modelo de los valores es prima facie lo mejor es, en el modelo de los principios, prima facie debido; y lo que en el modelo de los valores es definitivamente lo mejor es, en el modelo de los principios, definitivamente debido" (ALEXY. Teoría de los Derechos Fundamentales, p. 147).

69 Apenas para demarcar a dissonância, adianta-se que tese alexyana é refutada tanto por Dworkin quanto por Habermas, que defendem a impossibilidade de equiparar princípios a valores, sob pena de desnaturar a própria lógica de aplicação normativa. Ambos os autores ainda lançarão mão não de uma diferenciação morfológica entre princípios e regras, preferindo o que se pode considerar como uma distinção em razão da natureza lógico-argumentativa.

70 ALEXY. Constitutional Rights, Balancing and Rationality. Ratio Júris; SILVA. A constitucionalização do direito: os direitos fundamentais nas relações entre particulares, p. 25.

71 Afonso da Silva (O proporcional e o razoável, p. 24-27) sustenta que seria errônea a referência à técnica da ponderação como "princípio da proporcionalidade". Segundo o autor, "[o] chamado princípio da proporcionalidade não pode ser considerado um princípio, pelo menos não com base na classificação de Alexy, pois não tem como produzir efeitos em variadas medidas, já que é aplicado de forma constante, sem variações". Dessa forma, tratar-se-ia de uma regra de ponderação, aplicável por meio da subsunção, bem como suas sub-regras. Ávila (Repensando o "princípio da supremacia do interesse público sobre o particular". In: SARMENTO (Org.). Interesses públicos versus interesses privados: desconstruindo o princípio de supremacia do interesse público) refere-se a um dever de proporcionalidade, termo considerado correto por Afonso da Silva, mas pouco adequado, já que a idéia de dever remete apenas ao gênero norma jurídica, sem explicitar sua espécie - princípios ou regras. Também não se deve confundir proporcionalidade com racionalidade,
}

A\&C R. de Dir. Administrativo \& Constitucional, Belo Horizonte, ano 8, n. 33, p. 193-217, jul./set. 2008 
Assim, o próximo passo da presente explanação é analisar melhor o mecanismo da proporcionalidade teorizado por Alexy. Para tanto, deve-se lembrar que nem princípios nem regras são capazes de regular por si mesmos suas condições de aplicação, de modo que o jurista de Kiel reconhece a necessidade de promover uma compreensão da decisão jurídica regrada por uma teoria da argumentação. ${ }^{72}$ A partir disso, o sistema jurídico, além de conter regras e princípios, comporta um terceiro nível, no qual são feitas considerações sobre um procedimento — seguindo o modelo da razão prática — que permitiria alcançar e assegurar a racionalidade de aplicação jurídica. ${ }^{73}$

A argumentação jurídica é vista por Alexy ${ }^{74}$ como um caso especial da argumentação prática geral, ou seja, da argumentação moral. Sua peculiaridade, contudo, está na série de vínculos institucionais que a caracteriza, tais como a lei, o precedente e a dogmática jurídica. ${ }^{75}$ Mas mesmo esses vínculos - concebidos como um sistema de regras, princípios e procedimento - são incapazes de levar a um resultado preciso. As regras do discurso serviriam apenas para que se pudesse contar com um mínimo de racionalidade.

como lembra Afonso da Silva (O proporcional e o razoável, p. 28). Muitos juristas tratam como se fossem termos sinônimos, como se proporcionalidade fosse o termo adotado pelos autores de tradição germânica, ao passo que a razoabilidade tivesse sua difusão na tradição do common law. Segundo o constitucionalista, a diferenciação se dá não pela origem, mas pela estrutura. "A regra da proporcionalidade no controle das leis restritivas de direitos fundamentais surgiu por desenvolvimento jurisprudencial do Tribunal Constitucional alemão e não é uma simples pauta que, vagamente, sugere que os atos estatais devem ser razoáveis, nem uma simples análise da relação meio-fim. Na forma desenvolvida pela jurisprudência constitucional alemã, tem ela uma estrutura racionalmente definida, com subelementos independentes - a análise da adequação, da necessidade e da proporcionalidade em sentido estrito - , que são aplicados em uma ordem pré-definida e que conferem à regra da proporcionalidade a individualidade que a diferencia, claramente, da mera exigência de razoabilidade" (SILVA. O proporcional e o razoável. Revista dos Tribunais, p. 30). É, por isso, que esse autor afirma que o STF apenas consegue exercer sua função nos limites da razoabilidade, pouco ou nada compreendendo sobre a dimensão da proporcionalidade. O órgão judicante, então, apenas mencionaria as sub-regras da proporcionalidade, sem, contudo, analisá-las perante o caso específico que tem a sua frente.

72 "[...] el agregado del nivel de los principios conduce sólo condicionadamente a una vinculación en el sentido de una determinación estricta del resultado. También después de la eliminación de las lagunas de apertura a nivel de las reglas quedan las lagunas de indeterminación del nivel de los principios. Sin embargo, de aquí no podrían inferirse un argumento a favor del modelo de la regla e en contra del modelo regla/principio, tampoco si ésta fuera la última palabra. Lo que hasta ahora se ha descrito, el nivel de la regla y el de los principios, no proporciona un cuadro completo del sistema jurídico. Ni los principios ni las reglas regulan por sí mismos su aplicación. Si se quiere obtener un modelo completo, hay que agregar al costado pasivo uno activo, referido al procedimiento, de la aplicación de las reglas y los principios. Por lo tanto, los niveles de las reglas y los principios tienen que ser completados con un tercer nivel. En un sistema orientado por el concepto de la razón práctica, este tercer nivel puede ser sólo al de un procedimiento que asegura la racionalidad" (ALEXY. El concepto y la validez del derecho, p. 173, grifos nossos).

73 CHAMON JUNIOR. Tertium non datur": pretensões de coercibilidade e validade em face de uma teoria da argumentação jurídica no marco de uma compreensão procedimental do Estado Democrático de Direito. In: OLIVEIRA (Coord.). Jurisdição e hermenêutica constitucional no Estado Democrático de Direito, p. 103.

74 ALEXY. Derecho y Razón Práctica, p. 18.

75 Sobre isso, um maior detalhamento pode ser obtido pela leitura do capítulo 3 da obra ALEXY. Teoria da argumentação jurídica: a teoria do discurso racional como teoria da justificação jurídica.

A\&C R. de Dir. Administrativo \& Constitucional, Belo Horizonte, ano 8, n. 33, p. 193-217, jul./set. 2008 
Tudo, para Alexy, ${ }^{76}$ gira em volta de um problema referente à racionalidade jurídica. Como não é possível uma teoria moral de cunho substantivo, somente se pode apelar para as teorias morais procedimentais, que formulariam regras ou condições para a argumentação ou para uma decisão racional. ${ }^{77}$

Para desenvolver sua teoria da argumentação, o professor alemão irá proceder a uma minuciosa análise de diversas teorias, retirando delas o que considera notável, como lembra Souza Cruz:

Dos julgamentos morais de Stevenson, destacou as distintas formas de argumentos e de argumentações. Da filosofia lingüística de Wittgenstein, observou que a linguagem normativa não poderia ser reduzida à linguagem descritiva, ao passo que da Teoria Discursiva de Austin aproveitou os aspectos performativos da linguagem e sua relação com os dados da realidade.

Da teoria metaética de Hare, destacou o esforço na comensurabilidade de valores, ao exigir que o juiz não apenas se colocasse na posição do réu, mas que levasse a sério todos os interesses daqueles que de alguma forma pudessem ser afetados pela decisão, enquanto da filosofia psicológica de Toulmin aproveitou a concepção da existência de regras no discurso moral que permitiam um exame racional.

Da Teoria da Argumentação Moral de Baier notou que a argumentação prática possui regras distintas da argumentação desenvolvida nas ciências naturais, mas que ambas devem/podem ser taxadas como atividades racionais. Por sua vez, da Teoria do Consenso da Verdade de Habermas, ele percebeu que as ações são jogos de linguagem e que num discurso é possível depurar-se argumentos válidos de argumentos inválidos, em razão de sua aceitabilidade numa "situação ideal de discurso".

Contudo, ao entender que tal situação dificilmente ocorreria factualmente, Alexy estipulou o critério de Hare como condição mínima de sua teoria. Da Teoria da Liberação Prática da Escola de Erlanger, observou a necessidade da padronização da linguagem.

Finalmente, da Nova Retórica de Perelman assumiu a idéia de que não é possível definir um único resultado como correto e duradouro, dando abertura a um criticismo heurístico. ${ }^{78}$

Todo esse instrumental teórico irá contribuir para estruturar o procedimento da ponderação a partir de três sub-regras (regra de adequação,

\footnotetext{
${ }^{76}$ ALEXY. Derecho y Razón Práctica, p. 18-19.

77 Em consonância com essa afirmação, tem-se Souza Cruz (Jurisdição constitucional democrática, p. 164165), que observa que Alexy irá divergir da Corte Constitucional alemã, uma vez que essa exige a relativização de todos os direitos fundamentais, inclusive o da dignidade humana (ALEXY. Teoría de los Derechos Fundamentales, p. 108-109). Assim, a adoção pelo paradigma procedimental sustenta uma proteção aos direitos fundamentais por um aspecto dialógico do discurso e conforme a racionalidade do método de ponderação.

${ }_{78}$ CRUZ. Jurisdição constitucional democrática, p. 165-166.
}

A\&C R. de Dir. Administrativo \& Constitucional, Belo Horizonte, ano 8, n. 33, p. 193-217, jul./set. 2008 
regra da necessidade e regra da proporcionalidade em sentido estrito). Essas sub-regras são estruturadas de maneira a funcionarem sucessiva e subsidiariamente, mas nunca aleatoriamente $;^{79}$ por isso nem sempre será necessária uma análise de todas as três sub-regras. ${ }^{80}$

Em termos claros e concretos, com subsidiariedade quer-se dizer que a análise da necessidade só é exigível se, e somente se, o caso já não tiver sido resolvido com a análise da adequação; e a análise da proporcionalidade em sentido estrito só é imprescindível, se o problema já não tiver sido solucionado com as análises da adequação e da necessidade..$^{81}$

Afonso da Silva alerta que, no Brasil, difundiu-se o conceito de adequação como aquilo que é apto a alcançar o resultado pretendido ${ }^{82}$ Todavia, trata-se de uma compreensão equivocada da sub-regra, derivada da tradução imprecisa do termo alemão fördern como alcançar, ao invés de fomentar, o que seria mais correto. Nessa leitura:

\begin{abstract}
Adequado, então, não é somente o meio com cuja utilização um objetivo é alcançado, mas também o meio com cuja utilização a rejeição de um objetivo é fomentada, promovida, ainda que o objetivo não seja completamente realizado. Há uma grande diferença entre ambos os conceitos, que fica clara na definição de Martin Borowski, segundo a qual uma medida estatal é adequada quando o seu emprego faz com que o "objeto legítimo pretendido seja alcançado ou pelo menos fomentado". Dessa forma, uma medida somente pode ser considerada inadequada se sua utilização não contribuir em nada para fomentar a realização de objetivo pretendido. ${ }^{83}$
\end{abstract}

Pode-se tomar o exemplo da ADC $n^{\circ}$ 9-6 (racionamento de energia), como forma de esclarecer melhor o conteúdo da regra da adequação: para impedir o risco de questionamento judicial, principalmente dos artigos 14 a 18 da Medida Provisória n ${ }^{\circ}$ 2.152-2 - que disciplinava as metas de

\footnotetext{
79 "Se simplesmente as enunciarmos, independentemente de qualquer ordem, pode-se ter a impressão de que tanto faz, por exemplo, se a necessidade do ato estatal é, no caso concreto, questionada antes ou depois da análise da adequação ou da proporcionalidade em sentido estrito. Não é o caso. A análise da adequação precede a da necessidade, que, por sua vez, precede a da proporcionalidade em sentido estrito" (SILVA. O proporcional e o razoável. Revista dos Tribunais, p. 34).

80 "A impressão que muitas vezes se tem, quando se mencionam as três sub-regras da proporcionalidade, é que o juiz deve sempre proceder à análise de todas elas, quando do controle do ato considerado abusivo. Não é correto, contudo, esse pensamento. É justamente na relação de subsidiariedade acima mencionada que reside a razão de ser da divisão em sub-regras" (SILVA. O proporcional e o razoável. Revista dos Tribunais, p. 34).

81 SILVA. O proporcional e o razoável. Revista dos Tribunais, p. 34.

82 SARMENTO. A ponderação de interesses na Constituição Federal, p. 87; MENDES. A proporcionalidade na jurisprudência do Supremo Tribunal Federal. Repertório IOB de jurisprudência: tributário, constitucional e administrativo, p. 371.

83 SILVA. O proporcional e o razoável. Revista dos Tribunais, p. 37.
}

A\&C R. de Dir. Administrativo \& Constitucional, Belo Horizonte, ano 8, n. 33, p. 193-217, jul./set. 2008 
consumo de energia elétrica e previa as sanções no caso de descumprimento, foi proposta a ADC $n^{\circ} 9-6$, visando à declaração de constitucionalidade, com efeitos vinculantes. O STF entendeu, em sede de medida cautelar, que estava demonstrada a proporcionalidade e a razoabilidade das medidas tomadas pelo governo. Como lembra Afonso da Silva, o teste de adequação da medida deveria se limitar "ao exame de sua aptidão para fomentar os objetivos visados". ${ }^{84}$

Assim, mesmo que fosse questionável o fato de essas medidas tomadas serem as mais adequadas, para o constitucionalista, mostra-se inegável devido ao caráter coercitivo - que as medidas levariam os consumidores a economizarem energia elétrica e, mesmo que sozinhas não possam solucionar o problema de interrupção do fornecimento de energia elétrica, as medidas tomadas mostram-se capazes de colaborar para que o mesmo seja atingido. Por tal observação, elas poderiam ser consideradas adequadas nos termos exigidos pela proporcionalidade.

Mas será que elas poderiam passar também pelo grifo da regra de necessidade? Essa afirma o seguinte: "Um ato que limita um direito fundamental é somente necessário caso a realização do objetivo perseguido não possa ser promovida, com a mesma intensidade, por meio de outro ato que limite, em menor medida, o direito fundamental atingido". ${ }^{55}$ Segundo Sarmento, "impõe que o Poder Público adote sempre a medida menos gravosa possível para atingir a determinado objetivo". ${ }^{86}$ Assim, a adequação exige um exame absoluto do ato, ao passo que a necessidade, um exame comparativo,${ }^{87}$ isto é:

Suponha-se que, para promover o objetivo $\mathrm{O}$, o Estado adote a medida $\mathrm{M}_{1}$, que limita o direito fundamental $\mathrm{D}$. Se houver uma medida $\mathrm{M}_{2}$ que, tanto quanto $\mathrm{M}_{1}$, seja adequada para promover com igual eficiência o objetivo $\mathrm{O}$, mas limite o direito fundamental D em menor intensidade, então a medida $\mathrm{M}_{1}$, utilizada pelo Estado, não é necessária. ${ }^{88}$

Voltando ao exemplo do julgamento da ADC n ${ }^{\circ}$ 9-6, Afonso da Silva considera que as medidas tomadas pelo governo podem ser consideradas adequadas, por ajudarem a promover a economia de energia. Mas o exame

\footnotetext{
84 SILVA. O proporcional e o razoável. Revista dos Tribunais, p. 37.

85 SILVA. O proporcional e o razoável. Revista dos Tribunais, p. 38.

${ }^{86}$ SARMENTO. A ponderação de interesses na Constituição Federal, p. 88.

87 ALEXY. Derecho y Razón Práctica, p. 30.

88 SILVA. O proporcional e o razoável. Revista dos Tribunais, p. 38.
}

A\&C R. de Dir. Administrativo \& Constitucional, Belo Horizonte, ano 8, n. 33, p. 193-217, jul./set. 2008 
da necessidade exige que, primeiro, se identifique os direitos que serão limitados. Muitos, então, poderiam ser apontados como direitos possivelmente lesionados: direito de acesso a um serviço público, direito de igualdade, direito à livre iniciativa, direito ao trabalho, e, em última análise, o direito a uma vida digna. ${ }^{89}$

O passo seguinte seria identificar medidas alternativas que também pudessem satisfazer os objetivos da medida governamental. ${ }^{90}$ Se fosse demonstrada a existência — o que é bem plausível — de medida tão (ou até mais) adequada que as tomadas pelo governo, o STF teria de considerar a medida escolhida como desproporcional e, por isso, declarar a inconstitucionalidade da Medida Provisória no 2.152-2.

O último passo a ser verificado, a proporcionalidade em sentido estrito, apenas acontecerá depois de verificado que o ato é adequado $e$ necessário. ${ }^{91}$ Por isso,

[...] o exame da proporcionalidade em sentido estrito, que consiste em um sopesamento entre a intensidade da restrição ao direito fundamental atingido e a importância da realização do direito fundamental que com ele colide e que fundamenta a adoção da medida restritiva. ${ }^{92}$

Segundo Sarmento, ${ }^{93}$ há aqui um raciocínio baseado na relação custo-benefício da norma avaliada, isto é, o ônus imposto pela norma deve ser inferior ao benefício que pretende gerar. A constatação negativa deve ser tomada, portanto, como um juízo pela inconstitucionalidade do ato. Todavia,

[p] ara que uma medida seja reprovada no teste da proporcionalidade em sentido estrito, não é necessário que ela implique a não-realização de um direito fundamental. Também não é necessário que a medida atinja o chamado núcleo essencial de algum direito fundamental. Para que ela seja considerada desproporcional em sentido estrito, basta que os motivos que fundamentam a adoção da medida não tenham peso suficiente para justificar a restrição ao direito fundamental atingido. É possível, por exemplo, que essa restrição seja pequena, bem distante de implicar a não-realização de algum direito ou de atingir o seu núcleo essencial. Se a importância da realização do direito fundamental, no qual a limitação se baseia, não for suficiente para justificá-la, será ela desproporcional. ${ }^{94}$

\footnotetext{
${ }^{89}$ SILVA. O proporcional e o razoável. Revista dos Tribunais, p. 38-40.

90 Afonso da Silva (SILVA. O proporcional e o razoável. Revista dos Tribunais, p. 39-40) destaca que, durante o julgamento da ADC n० 9-6, deixou-se de proceder à identificação de medidas alternativas para a crise brasileira de energia, mesmo havendo outras soluções que foram apresentadas e discutidas pelos meios de comunicação na época. Logo, ficou prejudicada a aplicação da proporcionalidade neste caso específico.

91 ALEXY. Derecho y Razón Práctica, p. 31.

92 SILVA. O proporcional e o razoável. Revista dos Tribunais, p. 40.

93 SARMENTO. A ponderação de interesses na Constituição Federal, p. 89.

${ }^{4}$ SILVA. O proporcional e o razoável. Revista dos Tribunais, p. 41, grifo no original.
} 
No exemplo que até agora foi desenvolvido, o STF, por olvidar analisar a necessidade das medidas do governo, prejudicou a análise da proporcionalidade em sentido estrito.

Mas, em outro exemplo - ADI no 855-2 (pesagem de botijões de gás), a exigência de pesagem dos botijões de gás na presença dos consumidores foi considerada adequada pelo STF. Também pode ser considerada por Afonso da Silva ${ }^{95}$ necessária, pois a medida alternativa apresentada pesagem por amostragem - embora pudesse restringir em menor escala a livre iniciativa das empresas distribuidoras de gás, não pareceu ter a mesma capacidade de fomentar a proteção do consumidor. Assim, podese avançar para a análise da proporcionalidade em sentido estrito: verificar se a proteção ao consumidor se justifica em face da limitação à liberdade de iniciativa sofrida pelas empresas distribuidoras de gás. Para Afonso da Silva, ${ }^{96}$ o peso maior deveria ser dado à proteção do consumidor, todavia o entendimento do STF pendeu para uma solução inversa.

Evidenciar-se-ia, então, uma mudança em termos de compreensão do Supremo Tribunal Federal sobre a questão da supremacia do interesse público. Todavia, os julgados existentes ainda revelariam que o dogma persiste; o que se teria admitido seria apenas a relativização através da técnica de ponderação da supremacia do interesse público em algumas situações especiais, mas com um caminho aberto para revisão dessa compreensão. ${ }^{97}$

Cattoni de Oliveira, entretanto, apresenta outra leitura desse quadro:

O que eu discordo, em princípio, é quanto à afirmação de parte da doutrina atual segundo a qual, recentemente, o STF estaria relativizando o "princípio da supremacia do interesse público", ao ponderar, usando como critério a proporcionalidade, interesse público (estatal) e interesse privado. Não penso assim. Há uma tendência jurisprudencial a se relativizar, isto sim, a distinção entre questões políticas e questões jurídicas, com conseqüências para a compreensão da separação de poderes, para o papel do STF, para a práxis e para a metódica constitucionais. Por exemplo, ao considerar que, no exercício do controle concentrado, o STF exerce "tarefas não somente jurídicas mas políticas", ele é "legislador negativo", mas também "legislador positivo", ainda que excepcional, em prol de um "interesse público ou social maior". ${ }^{98}$

\footnotetext{
95 SILVA. O proporcional e o razoável. Revista dos Tribunais, p. 40-41.

96 SILVA. O proporcional e o razoável. Revista dos Tribunais, p. 41.

97 BARACHO JÚNIOR. A nova hermenêutica na jurisprudência do Supremo Tribunal Federal. In: SAMPAIO (Coord.). Crise e desafios da Constituição: perspectivas críticas da teoria e das práticas constitucionais brasileiras, p. 520.

98 OLIVEIRA. O Caso Ellwanger: uma crítica à ponderação de valores e interesses na jurisprudência recente do Supremo Tribunal Federal, p. 12.
}

A\&C R. de Dir. Administrativo \& Constitucional, Belo Horizonte, ano 8, n. 33, p. 193-217, jul./set. 2008 
A partir da crítica acima, deve ser posta uma questão: mesmo se o STF levasse a sério a ponderação - o que foi demonstrado que não ocorre, conforme a técnica desenvolvida por Alexy — poder-se-ia considerar essa uma resposta adequada ao paradigma procedimental do Estado Democrático de Direito?

Cattoni de Oliveira, ${ }^{99}$ pautando-se no pensamento de Habermas, ${ }^{100}$ apresentará uma resposta negativa à questão. Como problemas que pesem contra a sua utilização podem ser levantados os seguintes:

1. ao se admitir uma compreensão dos princípios jurídicos como mandamentos de otimização, aplicáveis de maneira gradual, Alexy emprega uma operacionalização própria dos valores: isso faria, então, com que os princípios perdessem a sua natureza deontológica, transformando o código binário do Direito em um código gradual; ${ }^{101}$

2. como conseqüência desse raciocínio, o Direito passaria a indicar o que é preferível, ao invés de o que é devido; ${ }^{102}$

3. o Direito - como pretensão de universalidade sobre a correção de uma ação - então, não mais pode ser considerado como

\footnotetext{
99 OLIVEIRA. Argumentação jurídica e decisionismo: um ensaio de teoria da interpretação jurídica enquanto teoria discursiva da argumentação jurídica de aplicação. In: SAMPAIO (Coord.). Crise e desafios da Constituição: perspectivas críticas da teoria e das práticas constitucionais brasileiras, p. 535.

${ }^{100}$ HABERMAS. Facticidad y Validez: sobre el derecho y el Estado democrático de derecho en términos de teoría del discurso, p. 347-333.

101 "O Direito, ao contrário do que defende uma jurisprudência dos valores, possui um código binário, e não um código gradual: que normas possam refletir valores, no sentido de que a justificação jurídico-normativa envolve questões não só acerca de o que é justo para todos (morais), mas também acerca de o que é bom, no todo e a longo prazo para nós (éticas), não que dizer que elas sejam ou devam ser tratadas como valores [...]" (OLIVEIRA. Direito constitucional, p. 88-89, grifos no original).

102 "....] normas - quer como princípios, quer como regras - visam ao que é devido, são enunciados deontológicos: à luz de normas, posso decidir qual é a ação ordenada. Já valores visam ao que é bom, ao que é melhor; condicionados a uma determinada cultura, são enunciados teleológicos: uma ação orientada por valores é preferível. Ao contrário das normas, valores não são aplicados mais priorizados" (OLIVEIRA. Direito constitucional, p. 90). Em outro texto, lembra o mesmo autor: "[...] ou nós estamos diante de uma conduta ilícita, abusiva, criminosa, ou então, do exercício regular, e não abusivo, de um direito. Tertium non datur! Como é que uma conduta pode ser considerada, ao mesmo tempo, como lícita (o exercício de um direito à liberdade de expressão) e como ilícita (crime de racismo, que viola a dignidade humana), sem quebrar o caráter deontológico, normativo, do Direito? Como se houvesse uma conduta meio lícita, meio ilícita?" (OLIVEIRA. O Caso Ellwanger: uma crítica à ponderação de valores e interesses na jurisprudência recente do Supremo Tribunal Federal, p. 6-7, grifos no original); é por isso mesmo que: "Esse entendimento judicial, que pressupõe a possibilidade de aplicação gradual, numa maior ou menor medida, de normas, ao confundilas com valores, nega exatamente o caráter obrigatório do Direito. Tratar a Constituição como uma ordem concreta de valores é pretender justificar a tese segundo a qual compete ao Poder Judiciário definir o que pode ser discutido e expresso como digno de valores, pois haveria democracia, nesse ponto de vista, sob o pressuposto de que todos os membros de uma sociedade política compartilham, ou tenham de compartilhar, de um modo comunitarista, os mesmos supostos axiológicos, uma mesma concepção de vida e de mundo. Ou, o que também é incorreto, que os interesses majoritários de uns devem prevalecer, de forma utilitarista, sobre os interesses minoritários de outros, quebrando assim, o princípio do reconhecimento recíproco de igual direitos de liberdade a todos" (OLIVEIRA. O Caso Ellwanger: uma crítica à ponderação de valores e interesses na jurisprudência recente do Supremo Tribunal Federal, p. 7, grifo no original).
}

A\&C R. de Dir. Administrativo \& Constitucional, Belo Horizonte, ano 8, n. 33, p. 193-217, jul./set. 2008 
um "trunfo", ${ }^{103}$ como quer Dworkin, nas discussões políticas que envolvam o bem-estar de uma parcela da sociedade; desnaturase, portanto, a tese de Rawls ${ }^{104}$ sobre a prevalência do justo sobre o bem;

4. além disso, a tese de Alexy nega a diferenciação entre discursos de justificação e discursos de aplicação, transformando a atividade judiciária em um poder constituinte permanente; e, por fim,

5. olvida-se da racionalidade comunicativa,${ }^{105}$ uma vez que todo o raciocínio é pautado a partir de uma racionalidade instrumental, deixando a aplicação jurídica a cargo de um raciocínio de adequação de meios a fins, ficando para segundo plano a questão da legitimidade da decisão jurídica; exatamente por isso o raciocínio sobre a ponderação acaba por cair em um decisionismo de cunho irracionalista, isto é, ausência de uma racionalidade comunicativa. ${ }^{106}$

Essas críticas servem para fomentar a discussão e sinalizam a necessidade de uma compreensão do Direito à luz do paradigma procedimental do Estado Democrático de Direito. Por isso, a proposta habermasiana desponta como a mais adequada. Mas as razões de tal opção transbordam os limites do presente artigo, devendo ser exploradas em outro estudo.

\begin{abstract}
The following article intent rebuilt the argumentative base of the STF's precedents in order to demonstrate that the public interest cannot assume supremacy over the private one. In Brazilian law, this understanding is a result of the use of the Robert Alexy's technique of "balancing" between principles. In the end, concludes such technique is not appropriate to a Constitutional Estate.
\end{abstract}

Keywords: Public and private interests; adjudication and conflict between principles; legitimacy of adjudication.

\footnotetext{
103 "[...] um direito não pode ser compreendido como um bem, mas como algo que é devido e não como algo que seja meramente atrativo. Bens e interesses, assim como valores, podem ter negociada a sua 'aplicação', são algo que se pode ou não optar, já que se estará tratando de preferências otimizáveis. Já direito não. Tão logo os direitos sejam compreendidos como bens e valores, eles terão que competir no mesmo nível que esses pela prioridade no caso individual. Essa é uma das razões pelas quais, lembra Habermas, Ronald Dworkin haver concebido os direitos como 'trunfos' que podem ser usados nos discursos jurídicos contra os argumentos de políticas" (OLIVEIRA. Direito constitucional, p. 90-91).

${ }^{104}$ RAWLS. Liberalismo político, p. 171; RAWLS. Justiça como eqüidade: uma reformulação, p. 199.

${ }^{105}$ HABERMAS. Facticidad y Validez: sobre el derecho y el Estado democrático de derecho en términos de teoría del discurso, p. 332

${ }^{106}$ Nesse sentido, Cattoni de Oliveira (OLIVEIRA. O Caso Ellwanger: uma crítica à ponderação de valores e interesses na jurisprudência recente do Supremo Tribunal Federal, p. 5) denuncia que, no caso do HC $\mathrm{n}^{\circ}$ 82.424-2 (Relator Min. Maurício Correia), o raciocínio de ponderação, que se supunha atingir uma solução objetiva para o caso concreto, acaba por atingir resultados contrários nos votos dos Min. Gilmar Mendes e Marco Aurélio ao buscar solucionar a suposta colisão entre dignidade humana e liberdade de expressão, tomados como valores.
}

A\&C R. de Dir. Administrativo \& Constitucional, Belo Horizonte, ano 8, n. 33, p. 193-217, jul./set. 2008 


\section{Referências}

ALEXY, Robert. Constitutional Rights, Balancing and Rationality. Ratio Júris, v. 16, n. 2, jun. 2003.

ALEXY, Robert. Derecho y Razón Práctica. 2. ed. México: Fontamara, 1998.

ALEXY, Robert. El concepto y la validez del derecho. 2. ed. Trad. Jorge M. Seña. Barcelona: Gedisa, 1997b.

ALEXY, Robert. Teoria da argumentação jurídica: a teoria do discurso racional como teoria da justificação jurídica. Tradução de Zilda Hutchinson Schild Silva. São Paulo: Landy, 2001.

ALEXY, Robert. Teoría de los Derechos Fundamentales. Trad. Ernesto Garzón Valdés. Madrid: Centro de Estudios Constitucionales, 1997.

ARAGÃO, Alexandre Santos. A “supremacia do interesse público” no advento do Estado de Direito e na Hermenêutica do direito público contemporâneo. In: SARMENTO, Daniel (Org.). Interesses públicos versus interesses privados: desconstruindo o princípio de supremacia do interesse público. Rio de Janeiro: Lumen Juris, 2005.

ÁVILA, Humberto. Repensando o "princípio da supremacia do interesse público sobre o particular”. In: SARMENTO, Daniel (Org.). Interesses públicos versus interesses privados: desconstruindo o princípio de supremacia do interesse público. Rio de Janeiro: Lumen Juris, 2005.

ÁVILA, Humberto. Teoria dos princípios: da definição à aplicação dos princípios jurídicos. 4. ed. São Paulo: Malheiros, 2004.

BANDEIRA DE MELLO, Celso Antônio. Curso de direito administrativo. 9. ed. São Paulo: Malheiros, 2003.

BARACHO JÚNIOR, José Alfredo de Oliveira. A nova hermenêutica na jurisprudência do Supremo Tribunal Federal. In: SAMPAIO, José Adércio Leite (Coord.). Crise e desafios da Constituição: perspectivas críticas da teoria e das práticas constitucionais brasileiras. Belo Horizonte: Del Rey, 2004.

BARROSO, Luís Roberto. O Estado contemporâneo, os direitos fundamentais e a redefinição da supremacia do interesse público. In: SARMENTO, Daniel (Org.). Interesses públicos versus interesses privados: desconstruindo o princípio de supremacia do interesse público. Rio de Janeiro: Lumen Juris, 2005.

BARROSO, Luís Roberto; BARCELLOS, Ana Paula de. O começo da história: a nova interpretação constitucional e o papel dos princípios no direito brasileiro. In: SAMPAIO, José Adércio Leite (Coord.). Crise e desafios da Constituição: perspectivas críticas da teoria e das práticas constitucionais brasileiras. Belo Horizonte: Del Rey, 2004.

BINENBOJM, Gustavo. Da supremacia do interesse público ao dever de proporcionalidade: um novo paradigma para o direito administrativo. In: SARMENTO, Daniel (Org.). Interesses públicos versus interesses privados: desconstruindo o princípio de supremacia do interesse público. Rio de Janeiro: Lumen Juris, 2005.

CARVALHO NETTO, Menelick de. Racionalização do ordenamento jurídico e democracia. Revista brasileira de estudos políticos, Belo Horizonte, n. 88, dez. 2003.

CARVALHO NETTO, Menelick de. Requisitos pragmáticos da interpretação jurídica sob o paradigma do Estado Democrático de Direito. Revista de Direito Comparado, Belo Horizonte, v. 3, maio 1999.

A\&C R. de Dir. Administrativo \& Constitucional, Belo Horizonte, ano 8, n. 33, p. 193-217, jul./set. 2008 
CHAMON JUNIOR, Lúcio Antônio. "Tertium non datur”: pretensões de coercibilidade e validade em face de uma teoria da argumentação jurídica no marco de uma compreensão procedimental do Estado Democrático de Direito. In: OLIVEIRA, Marcelo Andrade Cattoni de (Coord.). Jurisdição e hermenêutica constitucional no Estado Democrático de Direito. Belo Horizonte: Mandamentos, 2004.

CRUZ, Álvaro Ricardo de Souza. Jurisdição constitucional democrática. Belo Horizonte: Del Rey, 2004.

DI PIETRO, Maria Sylvia Zanella. Direito administrativo. 17. ed. São Paulo: Atlas, 2004.

DWORKIN, Ronald. Levando os direitos a sério. Tradução de Nelson Boeira. São Paulo: Martins Fontes, 2002. (Coleção Direito e Justiça).

FERREIRA, Rodrigo Mendes. Individualização e socialização em Jürgen Habermas: um estudo sobre a formação discursiva da vontade. São Paulo: Annablume, 2000.

GALUPPO, Marcelo Campos. Igualdade e diferença: Estado Democrático de Direito a partir do pensamento de Habermas. Belo Horizonte: Mandamentos, 2002.

GALUPPO, Marcelo Campos. Princípios jurídicos e a solução de seus conflitos: uma contribuição da obra de Alexy. Revista da Faculdade Mineira de Direito, Belo Horizonte, v. 1, n. 2, jun./dez. 1999.

GRONDIN, Jean. Introdução à hermenêutica filosófica. Tradução de Benno Dischinger. São Leopoldo: Unisinos, 1999. (Coleção Focus).

HABERMAS, Jürgen. A inclusão do outro: estudos de teoria política. Tradução de George Speiber e Paulo Astor Soethe. São Paulo: Loyola, 2002.

HABERMAS, Jürgen. Facticidad y Validez: sobre el derecho y el Estado democrático de derecho en términos de teoría del discurso. Trad. Manuel Jiménez Redondo. Madrid: Trotta, 1998.

HABERMAS, Jürgen. Pensamento pós-metafísico: estudos filosóficos. Tradução de Flávio Beno Siebeneichler. Rio de Janeiro: Tempo Brasileiro, 1990.

HABERMAS, Jürgen. Teoría de la acción comunicativa. Trad. Manuel Jiménez Redondo. Madrid: Taurus, 1987. 2 v. (Tomo I: Racionalidad de la acción y racionalización social; Tomo II: Crítica de la razón funcionalista).

HART, H. L. A. O conceito de direito. 2. ed. Trad. A. Ribeiro Mandes. Lisboa: Fundação Calouste Gulbenkian, 1994.

KELSEN, Hans. Teoria pura do direito. 6. ed. Tradução de João Batista Machado. São Paulo: Martins Fontes, 1999.

MENDES, Gilmar Ferreira. A proporcionalidade na jurisprudência do Supremo Tribunal Federal. Repertório IOB de jurisprudência: tributário, constitucional e administrativo, n. 23, 1994.

MÜLLER, Friedrich. Quem é o povo?: a questão fundamental da democracia. Tradução de Peter Naumann. São Paulo: Max Limmonad, 1998.

OLIVEIRA, Marcelo Andrade Cattoni de. Argumentação jurídica e decisionismo: um ensaio de teoria da interpretação jurídica enquanto teoria discursiva da argumentação jurídica de aplicação. In: SAMPAIO, José Adércio Leite (Coord.). Crise e desafios da Constituição: perspectivas críticas da teoria e das práticas constitucionais brasileiras. Belo Horizonte: Del Rey, 2004.

A\&C R. de Dir. Administrativo \& Constitucional, Belo Horizonte, ano 8, n. 33, p. 193-217, jul./set. 2008 
OLIVEIRA, Marcelo Andrade Cattoni de. Direito constitucional. Belo Horizonte: Mandamentos, 2002.

OLIVEIRA, Marcelo Andrade Cattoni de. Direito processual constitucional. Belo Horizonte: Mandamentos, 2001.

OLIVEIRA, Marcelo Andrade Cattoni de. O Caso Ellwanger: uma crítica à ponderação de valores e interesses na jurisprudência recente do Supremo Tribunal Federal. Disponível em: < http://www.leniostreck.com.br/midias/ArtigoCaso Ellwanger.doc $>$. Acesso em: 3 jan. 2006 .

RAWLS, John. Justiça como eqüidade: uma reformulação. Tradução de Claudia Berliner. São Paulo: Martins Fontes, 2003. (Coleção Direito e Justiça).

RAWLS, John. Liberalismo político. Trad. Sergio René Madero Báez. México: Fondo de Cultura Econômica, 1996. (Política y Derecho).

RODRIGUES, Leda Boechat. História do Supremo Tribunal Federal: da defesa das liberdades civis. 2. ed. Rio de Janeiro: Civilização Brasileira, 1991. 2 v.

ROSENFELD, Michel. A identidade do sujeito constitucional. Tradução de Menelick de Carvalho Netto. Belo Horizonte: Mandamentos, 2003.

SALLES, Carlos Alberto de. Processo civil de interesse público. In: SALLES, Carlos Alberto de (Org.). Processo civil e interesse público: o processo como instrumento de defesa social. São Paulo: Revista dos Tribunais, 2003.

SARMENTO, Daniel. A ponderação de interesses na Constituição Federal. Rio de Janeiro: Lumen Juris, 2000.

SARMENTO, Daniel. Interesses públicos vs. Interesses privados na perspectiva da Teoria e da Filosofia Constitucional. In: SARMENTO, Daniel (Org.). Interesses públicos versus interesses privados: desconstruindo o princípio de supremacia do interesse público. Rio de Janeiro: Lumen Juris, 2005.

SILVA, Virgílio Afonso da. A constitucionalização do direito: os direitos fundamentais nas relações entre particulares. São Paulo: Malheiros, 2005. (Teoria \& Direito Público)

SILVA, Virgílio Afonso da. O proporcional e o razoável. Revista dos Tribunais, São Paulo, ano 91, v. 798, abr. 2002.

SOUZA JÚNIOR, Antonio Umberto. O Supremo Tribunal Federal e as questões políticas: o dilema brasileiro entre o ativismo e a autocontenção no exame judicial das questões políticas. Porto Alegre: Síntese, 2004.

STRECK, Lenio Luiz. A crise da hermenêutica e a hermenêutica da crise: a necessidade de uma nova crítica do direito (NCD). In: SAMPAIO, José Adércio Leite (Coord.). Jurisdição constitucional e direitos fundamentais. Belo Horizonte: Del Rey, 2003.

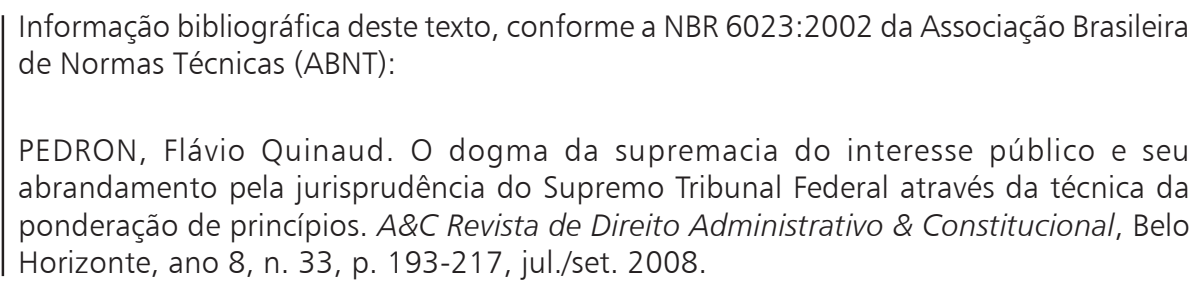

A\&C R. de Dir. Administrativo \& Constitucional, Belo Horizonte, ano 8, n. 33, p. 193-217, jul./set. 2008 